UDC 332.1

DOI: https://doi.org/10.32782/2413-9971/2021-36-21

Poliakova Juliia

Doctor of Economic Sciences,

Senior Lecturer at Department of International Economic Relation

Lviv University of Trade and Economics

Yaremko Larysa

Doctor of Economic Sciences,

Senior Lecturer at Department of International Economic Relation

Lviv University of Trade and Economics

Bublei Galyna

PhD in Economics,

Senior Lecturer at Department of International Economic Relation Zaporizhzhya Institute of Economics and Information Technology

Полякова Ю. В. доктор економічних наук, дочент кафедри міжнародних економічних відносин Львівського торговельно-економічного університету

Яремко Л. А.

доктор економічних наук, професор кафедри міжнародних економічних відносин Львівського торговельно-економічного університету

Бублей Г. А.

кандидат економічних наук, дочент кафедри міжнародних економічних відносин та підприємництва, Запорізького інституту економіки та інформаційних технологій

\title{
INCLUSIVE DEVELOPMENT OF UKRAINE'S REGIONS IN THE CONDITIONS OF EUROPEAN INTEGRATION
}

Summary. The article is devoted to substantiate the foundations of an increase of the level of inclusiveness of economic development of the regions of Ukraine on the basis of development of the strategy of reasonable specialization. The directions of implementation of the EU member states' experience on ensuring economic development on the basis of inclusiveness in the strategic programme documents of Ukraine are highlighted. The importance of using innovation in the process of ensuring inclusive economic growth and social well-being is emphasized and the relationship between innovation, inclusiveness and well-being is shown. The assessment of differentiation of social and economic development of the regions of Ukraine is carried out. The stages and directions of development of the regional strategy of smart specialization for the regions of Ukraine, which provides for the use of innovation results, construction of new innovative business models with a focus on solving social problems and ensuring a high level of community welfare based on the European experience.

Key words: innovation activity, regional policy, inclusiveness, development strategy, European integration.

Introduction and problem statement. The issues of ensuring economic growth of countries and regions on the basis of inclusiveness, which means the inclusion of all citizens in economic development, increasing their participation, obtaining results and avoiding isolation in order to achieve appropriate standards and ensure a high quality of life, are becoming relevant in today's world. At the regional level, inclusiveness is more clearly seen as a means of achieving the well-being of all members of the regional community by using existing and creating new resources for development. Governments and international organizations pay close attention to and include in their development programmes aspects related to the concept of inclusive activities. Current EU regional policy priorities are based on the principles of solidarity, promoting economic progress, improving living conditions and standards, and correlate with the three areas of smart, sustainable and inclusive growth, which contribute to finding answers to global challenges. Over a long period of time, the EU regional policy has been accompanied by institutional changes, including the adoption of relevant directives and recommendations, the conclusion of multilateral agreements, the establishment and modernization of various funds, the selection and justification of priorities, tools and mechanisms to achieve and monitor objectives.

Analysis of research and publications. In the scientific literature, the issues of forming conceptual foundations, studying the factors influencing the intensification of development on the principles of inclusiveness in the global and national dimensions have been considered in detail. Methodological, institutional, scientific and applied aspects of inclusive economic development at different levels are topical issues of scientific research of many domestic scientists, including V. Adamyk, A. Hutorov, D. Lebid, O. Prohnimak, O. Prodius, L. Fedulova. The institutionalization of Ukraine's European choice and the implementation of the provisions of the Association Agreement between the EU and Ukraine determine the importance of an inclusive development model at the regional level.

The object of the article is to study the basic principles of increasing the level of inclusiveness of economic development 
of the regions of Ukraine on the basis of developing its own strategy of smart specialization.

Results and analysis. Changes in the target direction and applied methodological approaches to the formation of the EU regional policy are due to the impact of globalization challenges, the needs of civil society development, the importance of sustainable growth. Accordingly, the role of regions is undergoing transformation, as not only the priority of achieving certain socio-economic indicators is growing but also the degree of involvement in world economic processes.

Among the characteristic features of the modern European model of regional policy there are the following $[1$, p. 7]: creation of a favourable regulatory environment, macroeconomic stability and equal framework conditions for doing business; application of development strategies that take into account the needs and motivations of the region using appropriate economic tools; stimulating cross-border, transnational, and interregional cooperation; implementation of a special policy on urban agglomerations as drivers of economic growth and a source of problems for sustainable spatial development; awareness of the importance for regional development of small and medium-sized cities and local centers of rural areas; support for local employment initiatives and capacity building.

The EU regional policy is coordinated with sectoral development policies. At the European level, the functional purpose of regional policy is being transformed by moving away from equalizing the levels of regional development to smooth differentiation to creating favourable conditions for self-development.

Modern EU regional policy is aimed at achieving economic cohesion based on the principles of inclusiveness and sustainable development. Imperatives formed under the influence of global economic integration acquire regional specificity and at the same time a policy of cohesion is formed. Regional policy is implemented through strategic development programmes with clearly defined guidelines and appropriate financial support.

The State Strategy for Regional Development for 2021-2027 adopted at the state level in Ukraine is the main planning document for the implementation of sectoral development strategies, coordination of state policy in various areas, achieving efficient use of state resources in territorial communities and regions in the interests of human, state unity, sustainable development of historical settlements and preservation of the traditional character of the historical environment, preservation of the natural environment and sustainable use of natural resources for present and future generations of Ukrainians [2].

Analysis of the practice of applying effective mechanisms of EU regional and innovation policies is important for Ukraine. The Association Agreement between the EU and Ukraine stipulates that cooperation between the parties is aimed at involving Ukraine in the European Research Area to help strengthen the competitiveness of the economy. To this end, the Agreement defines: exchange of information on policy in the field of science and technology; participation in the EU Framework Programmes for Research and Innovation; joint implementation of scientific programmes and research activities; training through the implementation of exchange programmes for scientists and specialists; joint research on scientific progress, technology transfer and know-how; organization of joint events on scientific and technological development; formation of preconditions for research and implementation of the results of intellectual work, as well as proper protection of intellectual property, etc. [3].
The importance of implementing the experience of the EU member states is outlined in domestic strategic policy documents. Thus, the National Report "Sustainable Development Goals" states that the justification of strategic development goals should be based on national and global challenges of resource, social, environmental, institutional origin. These tasks should be based on the provisions of the Deep and Comprehensive Free Trade Agreement with the EU. According to the Sustainable Development Strategy of Ukraine until 2030, strategic goals are achieved on the basis of inclusiveness. In particular, the first strategic goal is "Promoting inclusive balanced low-carbon economic growth and sustainable infrastructure" with operational objectives: promoting long-term inclusive balanced economic growth, full and productive employment and decent work for all; creation of sustainable infrastructure, inclusive energy efficient and innovative industrial development and the seventh strategic goal "Ensuring security and access to justice, creating accountable and inclusive institutions" with operational objectives: promoting peaceful and inclusive communities for sustainable development and state security; access to justice and protection of rights for all; creating effective, accountable and inclusive institutions at all levels.

To the main factors that determine the need to intensify development on the basis of inclusiveness in Ukraine V. Adamyk and D. Lebid include the following: low level of infrastructure development and its heterogeneity in terms of regions; low quality of education, which reduces the opportunities to obtain thorough knowledge and practical skills to increase the income of individuals; difficulties in conducting medium and small business; a large share of the shadow economy, which makes it impossible to direct the real amount of national income to economic development and maintaining living standards; unavailability of quality medical services and medicines for the average Ukrainian, which reduces the average life expectancy and quality of life; a significant percentage of so-called "marginal" persons in the population structure, which is explained by a large gap in income in the absence of an adequate system of social and legal protection $[4$, p. 66].

According to O. Hutorov, inclusive development covers the processes of economic growth and development, takes into account the anthropogenic load on the ecosystem, as well as the nature of socio-economic transformations. It is accompanied by the formation of the knowledge economy, noosphere and cultural development of society, modernization of the economic management system on the basis of planning, interactivity, publicity and democratic centralism in decisionmaking [5, p. 30]. O. Prohnimak notes that inclusive growth allows to attract most of the labour resources to efficient economic activity and provide the majority of the population with a high standard of living [6, p. 188].

O. Prodius argues that the concept of inclusive development implies the following: each economic entity is important, unique, valuable to society and has the opportunity to meet their needs. Inclusive economic growth is a multifactorial and multilevel process, the basis of which is the economy of maximum employment and interaction of all actors in the context of humane development of society [7, p. 85].

Accordingly, ensuring the well-being and high indicators of socio-economic development of the regions should be based on inclusiveness and the use of the results of innovation (Figure 1).

Innovation issues should be central to the use of available human capital. At this stage in Ukraine, with high indicators of human capital development, the effectiveness of innovation remains low. In 2019, according to the sub-index "Human Capital and Research", Ukraine lost 8 more positions and 


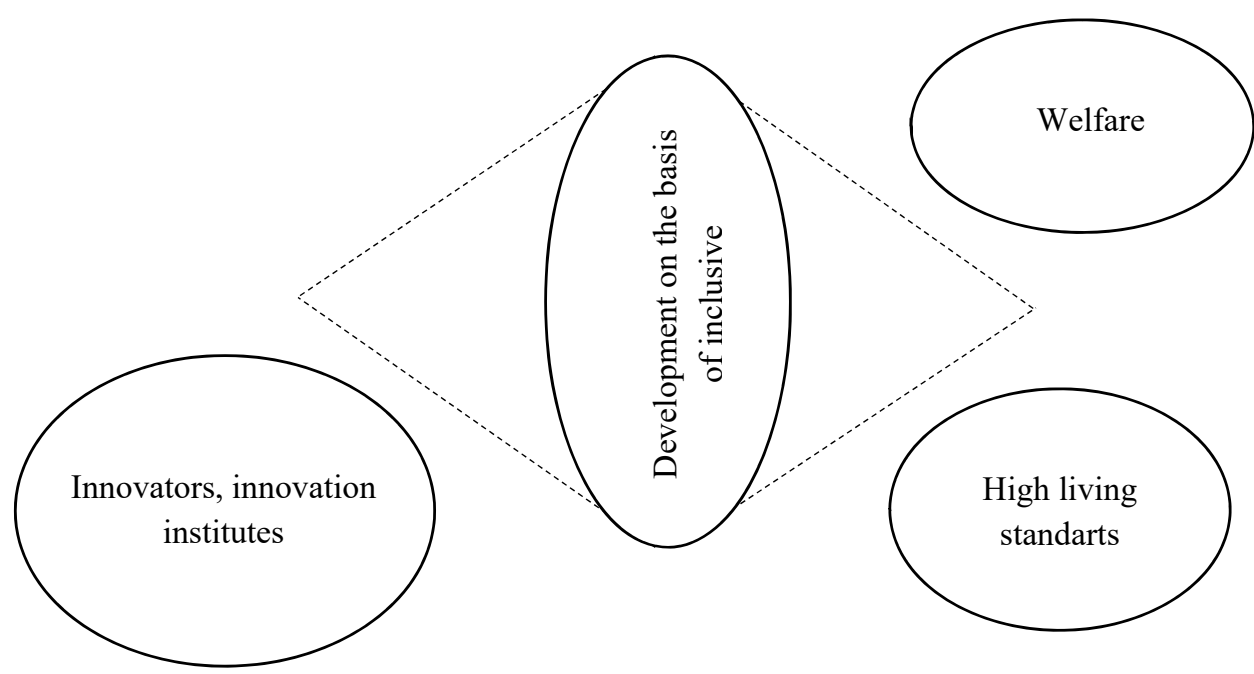

Figure 1. The relationship between innovation, inclusiveness and well-being

Source: developed by the authors

was in 51st place. The reason for this was the reduction of education expenditures as a percentage of GDP (22nd place in 2017 , 26th place in 2018, 48th place in 2019) and R\&D expenditures as a percentage of GDP (54th place in 2017 , 62nd place in 2018, 67th place in 2019) [9, p. 7].

According to a report published by the Global Innovation Index 2019, prepared by Cornell University, the INSEAD Business School and the World Intellectual Property Organization, Switzerland (Sweden), Sweden, the United States, the Netherlands and the United Kingdom lead the ranking of leading innovators.

The ten most innovative countries in the world also include: Finland, Denmark, Singapore, Germany and Israel (Figure 2).

The report examines the relationship between global economic growth and innovation. As global economic growth declines in 2019, the question is whether this trend will continue. There are two problems: 1) the global innovation index shows that government spending on $\mathrm{R} \& \mathrm{D}$, particularly in some high-income countries responsible for technology development, is growing slowly or not at all; 2) strengthening protectionism, in particular that which affects knowledgeintensive industries and knowledge flows, creates risks for global innovation networks and the spread of innovation. If these new barriers to international trade, investment and labor mobility are ignored, it will slow down productivity growth and spread it around the world.

In 2019, Ukraine lost four positions in the ranking and took 47th place, ahead of Georgia (48th place). In the group of countries in terms of income below the average, Ukraine took second place, behind Vietnam.

Differentiation of indicators of socio-economic development of the regions of Ukraine per capita, which can

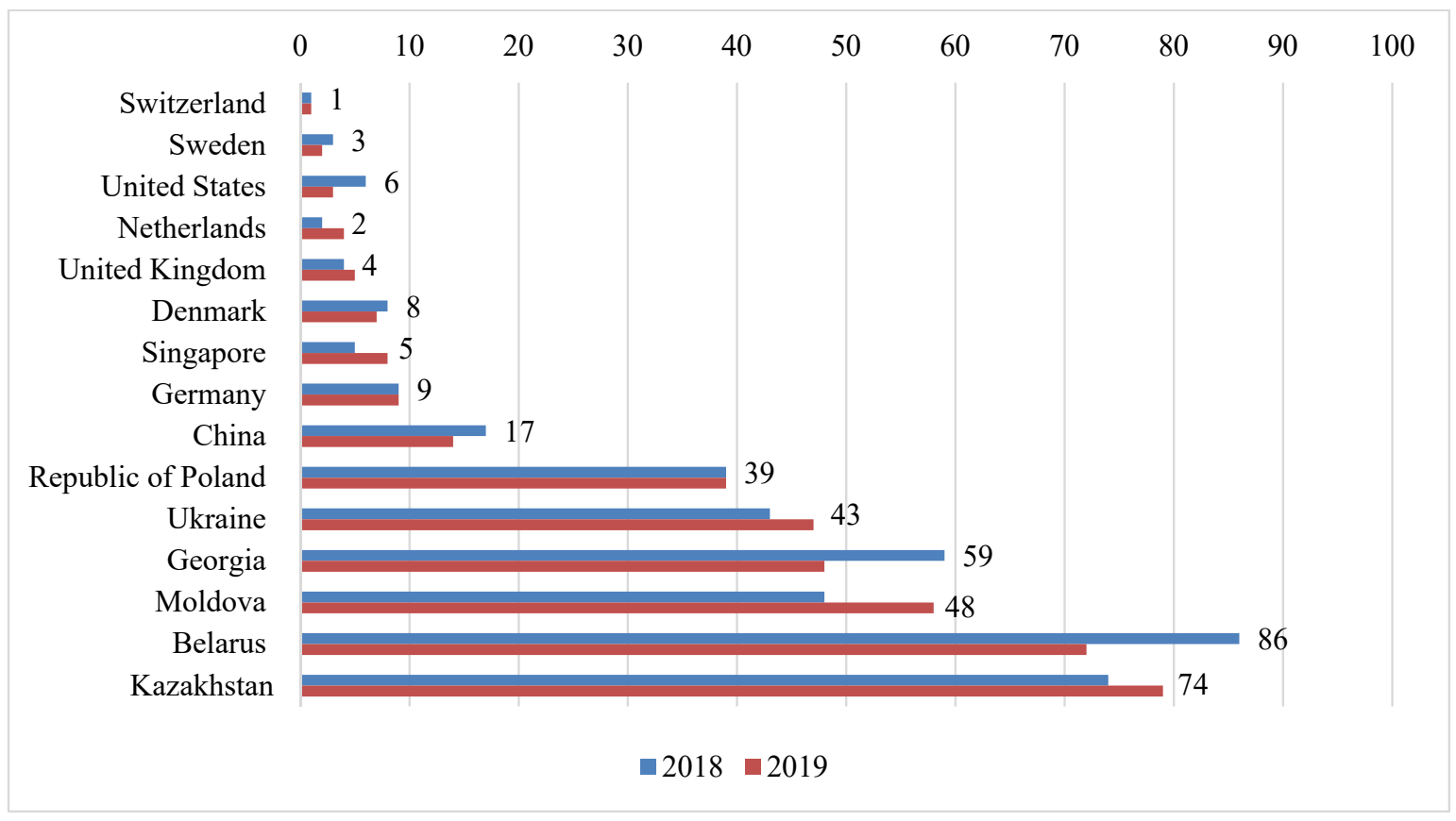

Figure 2. Dynamics of the Global Innovation Index by country for 2018-2019 


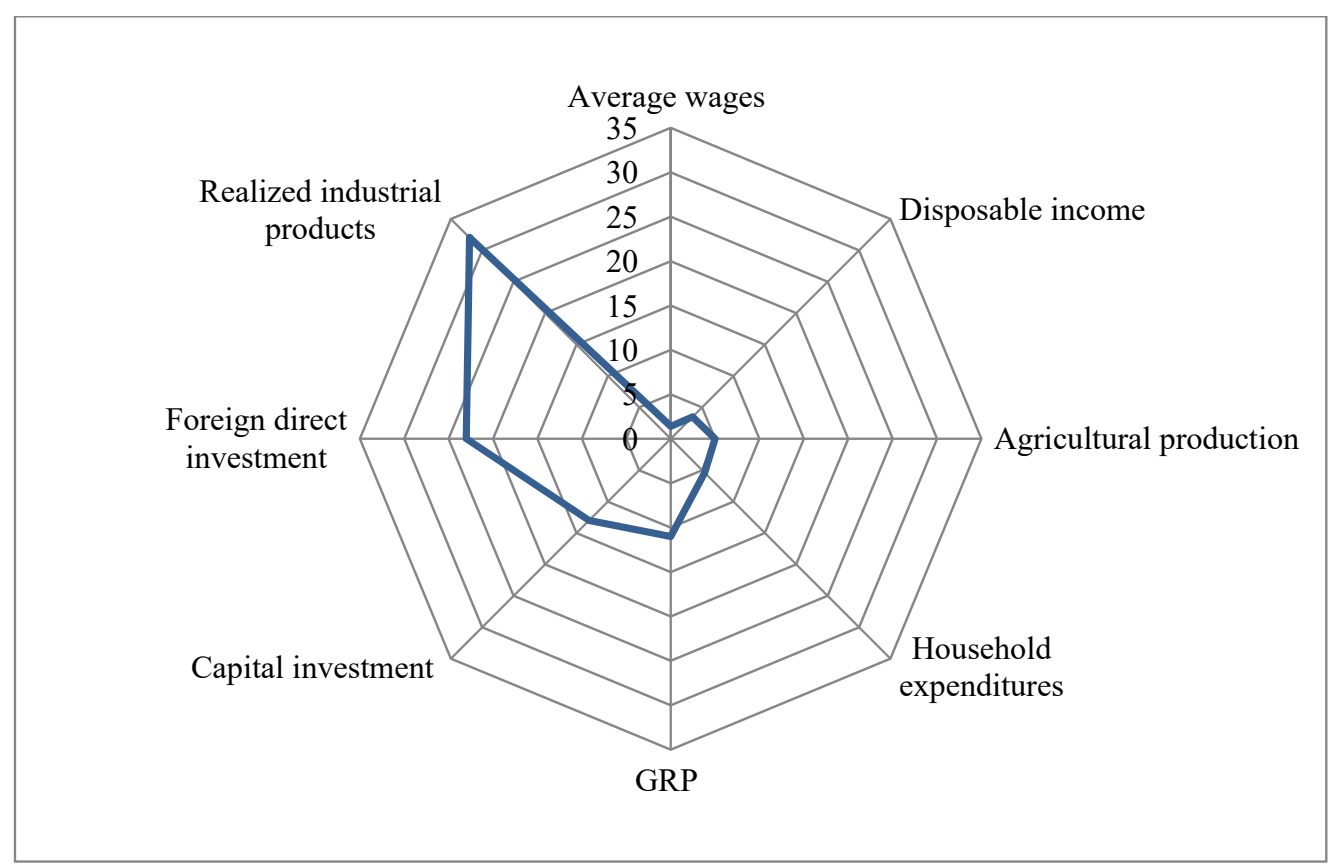

Figure 3. Differentiation of indicators of socio-economic development of the regions of Ukraine per capita Source: [10]

demonstrate the degree of inclusiveness, shows that the disparity in gross regional product is 11 times, disposable income - 3.5, household expenditures - 5.4, average wages -1.4 , capital investment -13 , sales of industrial products -32 , agricultural production -4.6 , foreign direct investment -23 (Figure 3). The gap in production and investment (the functioning of the economic system of the region) is more significant than in disposable income and average wages (living standards). It can be agreed that such stratification in the development of regions within the country shows an inefficient model of inclusive development.

Inclusiveness of regional development should be achieved as a justification of regional development priorities and positioning at the national level. European experience shows the feasibility of developing a regional smart specialization strategy within the Smart Specialization Platform initiative as a definition of the region's unique characteristics (economic areas, their combination with new fast-growing industries) to develop competitive advantages or concentrate resources to achieve goals.

For Ukrainian practice, this should be understood as finding a niche for the region based on the use of information on innovation, building new innovative business models with a focus on solving social problems (environment, employment, overcoming social inequality) and ensuring high level of community welfare. The process will take place within three stages, at each of them the necessary measures are taken and the criteria for their achievement are determined (Figure 4).

Regional smart specialization strategies are aimed at achieving a common goal - technological and non-technological transformation of endogenous development potential in the region. They should be formed as a result of research, public discussion and creation of an appropriate institutional system that includes inclusiveness and use of the following principles; taking into account the current economic and educational specialization, scientific and technological structure of the region; creating preconditions for intersectoral relations that intensify diversification processes; inclusion in innovative processes of educational institutions, companies, state and regional bodies.

An important place in the development and implementation of the strategy should be given to inclusive innovations, which, according to L. Fedulova, are non-technical, and their implementation generates social benefits by creating employment opportunities and solving specific problems facing low-income groups [11, p. 58]. In our opinion, this approach will help reduce social inequality.

Researchers have shown that most EU countries have developed and approved smart specialization strategies, which are national or regional strategies that prioritize competitive advantages by developing and matching the strengths of scientific and innovative aspects of the region/industry with the requirements of business; market development through cohesion, while avoiding duplication and fragmentation. The strategy of smart specialization can be developed separately, and can be included in the national or regional scientific and innovation strategy [12, p. 28].

The implementation of smart specialization strategies by the regions of Ukraine should ensure that the regions have the opportunity to determine their own development strategy; overcoming excessive interregional disparities in development, involving local communities in realizing the existing potential and solving local problems; achieving a high level of quality of life; ensuring sustainable development of territories; as a result, contribute to increasing the competitiveness and balanced development of the regions in the process of Ukraine's integration into $t$ he EU.

Conclusions. Renewal of the concept of regional policy of the EU member states is due to global geopolitical challenges, development of cooperation between countries, improvement of institutional support, increasing the importance of inclusiveness in achieving the goals of socio-economic growth and well-being of citizens through innovation activity. The importance of implementing the EU experience is emphasized in the programme strategic documents of Ukraine and is regulated by the provisions of 


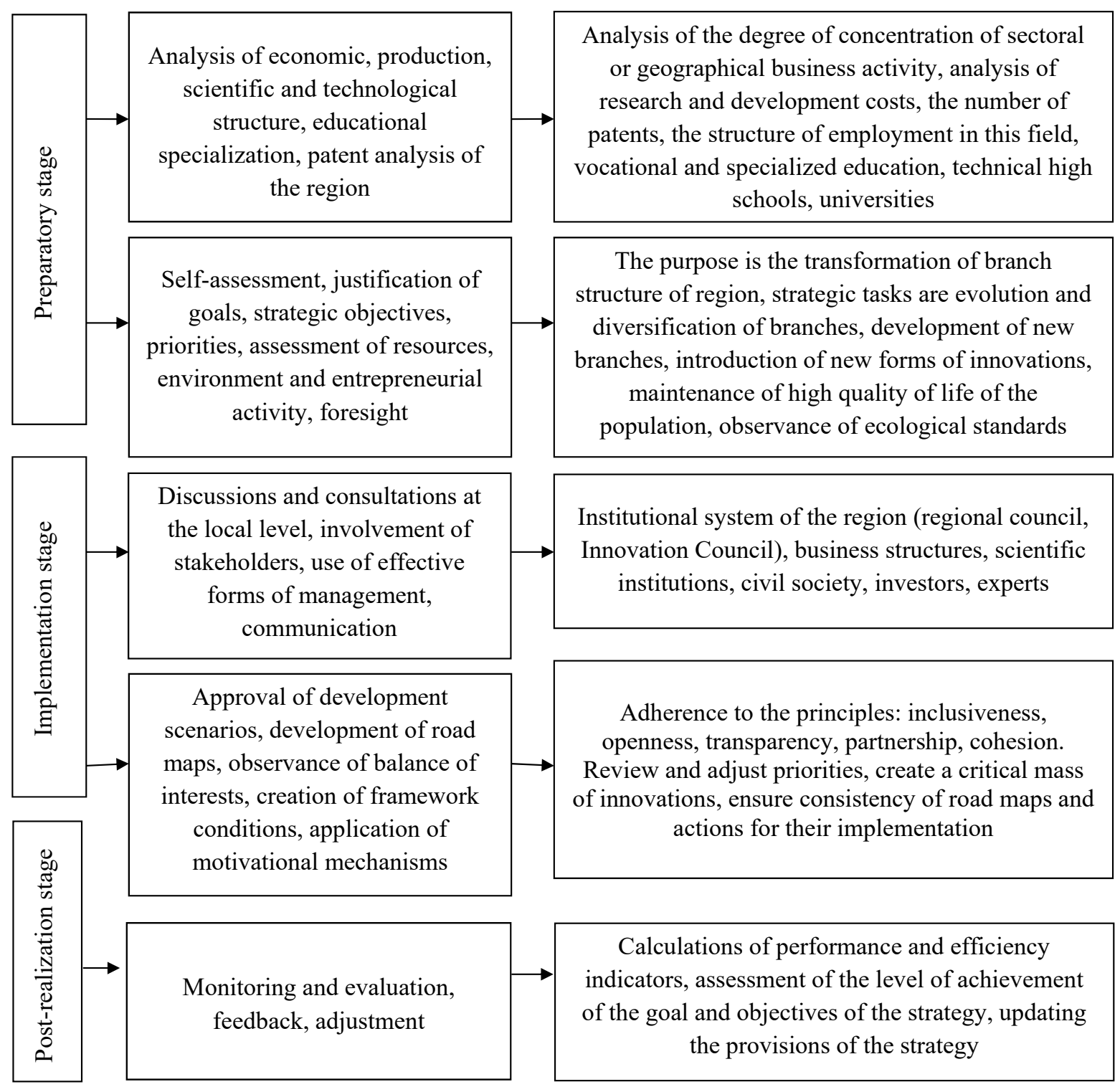

Figure 4. Approaches to the development of a strategy for smart specialization of the regions of Ukraine on the basis of inclusiveness

the Association Agreement between the EU and Ukraine. One of the areas of implementation of these aspects is the development and implementation of strategies for smart specialization on the basis of inclusiveness in the regions inequality. of Ukraine based on the adaptation of smart specialization approaches of the EU member states, which directly involves long-term structural innovation in the region in global markets, ensuring prosperity and eliminating social

\section{References:}

1. Nova rehionalna polityka dlia novoi Ukrainy: Analitychna dopovid (2017) [New Regional Policy for New Ukraine: An Analytical Report]. Kyiv: Instytut suspilno-ekonomichnykh doslidzhen.

2. Derzhavna stratehiia rehionalnoho rozvytku na 2021-2027 roky (2020) [State Strategy for Regional Development for 2021-2027]. Available at: https://zakon.rada.gov.ua (accessed 10 April 2021).

3. Government portal (2015). Uhoda pro Asotsiatsiiu [Association Agreement]. Available at: www.kmu.gov.ua (accessed 02 March 2021).

4. Adamyk V., Lebid D. (2018) Inkliuzyvnyi rozvytok krainy ta mizhnarodne finansove i tekhnichne spivrobitnytstvo z yoho aktyvizatsii [Inclusive development of the country and international financial and technical cooperation for its activation]. Bulletin of Ternopil National Economic University, no. 1, pp. 56-68.

5. Hutorov A.O. (2019) Inkliuzyvnyi rozvytok ekonomiky i ahrarnoi sfery (teoriia, metodyka, analiz) [Inclusive development of economy and agrarian sphere (theory, methodology, analysis)]. Kharkiv: Tochka. (in Ukrainian)

6. Prohnimak O.D. (2018) Inkliuzyvnyi rozvytok Ukrainy: pereshkody vs perspektyvy [Inclusive development of Ukraine: obstacles vs prospects]. Economic Bulletin of Donbass, no. 1 (51), pp. 187-197.

7. Prodius O.I. (2017) Inkliuzyvni innovatsii v konteksti sotsialnoi vidpovidalnosti pidpryiemstva [Inclusive innovations in the context of corporate social responsibility]. Scientific Bulletin of Uzhgorod National University, vol. 14, pp. 84-44. 
8. The Global Innovation Index 2018. Available at: https://www.globalinnovationindex.org/gii-2018-report (accessed 15 April 2021).

9. The Global Innovation Index 2019. Available at: https://www.globalinnovationindex.org/gii-2019-report (accessed 15 April 2021).

10. Derzhavna sluzhba statystyky Ukrainy (2019) Statystychnyi zbirnyk "Rehiony Ukrainy" [Statistical collection "Regions of Ukraine"]. Kyiv: Informatsiino-analitytchne ahentstvo.

11. Fedulova L.I. (2016) Inkliuzyvni innovatsii v systemi sotsialno-ekonomichnoho rozvytk [Inclusive innovations in the system of socio-economic development]. Economy: the realities of time, no. 3(25), pp. 56-65.

12. Terytorialnyi rozvytok i rehionalna polityka. Stratehuvannia rehionalnoho rozvytku na zasadakh smart-spetsializatsii: naukova dopovid [Territorial development and regional policy. Regional development strategy on the basis of smart specialization: a scientific report] (eds. Storonianska I.). Lviv: IRD NANU, p. 141.

\section{Список використаних джерел:}

1. Нова регіональна політика для нової України: Аналітична доповідь. Київ, Інститут суспільно-економічних досліджень, 2017. $76 \mathrm{c}$.

2. Державна стратегія регіонального розвитку на 2021-2027 роки. URL: https://zakon.rada.gov.ua (дата звернення: 10.04.2021).

3. Угода про Асоціацію між Україною та CC. URL: www.kmu.gov.ua. (дата звернення: 02.03.2021).

4. Адамик В., Лебідь Д. Інклюзивний розвиток країни та міжнародне фінансове і технічне співробітництво 3 його активізації. Вісник Тернопільського національного економічного університету. 2018. №1. С. 56-68.

5. Гуторов А. О. Інклюзивний розвиток економіки і аграрної сфери (теорія, методика, аналіз). Харків : Точка, 2019.146 с.

6. Прогнімак О. Д. Інклюзивний розвиток України: перешкоди vs перспективи. Економічний вісник Донбасу. 2018. № 1(51). C. $187-197$.

7. Продіус О. І. Інклюзивні інновації в контексті соціальної відповідальності підприємства. Науковий вісник Ужсгородського національного університету. 2017. Вип. 14. Ч. 2. С. 84-88.

8. The Global Innovation Index 2018. URL: https://www.globalinnovationindex.org/gii-2018-report (дата звернення: 15.04.2021).

9. The Global Innovation Index 2019. URL: https://www.globalinnovationindex.org/gii-2019-report (дата звернення: 15.04.2021).

10. Статистичний збірник “Регіони України”. Київ : Державна служба статистики України, 2019. Ч. 1. 309 с.

11. Федулова Л.І. Інклюзивні інновації в системі соціально-економічного розвитку. Економіка: реалії часу. 2016. № 3(25). С. 56 -65.

12. Територіальний розвиток і регіональна політика. Стратегування регіонального розвитку на засадах смарт-спеціалізації: наукова доповідь / наук. ред. І. Сторонянська. Львів, ІРД НАНУ. 2020. 141 с.

\section{ИНКЛЮЗИВНОЕ РАЗВИТИЕ РЕГИОНОВ УКРАИНЫ В УСЛОВИЯХ ЕВРОИНТЕГРАЦИИ}

Аннотация. Статья посвящена разработке базовых основ повышения уровня инклюзивности экономического развития регионов Украины на основе разработки собственной стратегии разумной специализации. Освещены направления имплементации опыта стран-членов ЕС по обеспечению экономического развития на основе инклюзивности в стратегических программных документах Украины. Подчеркнута важность использования инновационной деятельности в процессе обеспечения инклюзивного экономического роста и социального благополучия и показана взаимосвязь между инновационной деятельностью, инклюзивность и благосостоянием.

Проведена оценка дифференциации социально-экономического развития регионов Украины. Предложены этапы и направления разработки региональной стратегии разумной специализации для отечественных регионов, что в свою очередь предусматривает использование результатов инновационной деятельности, построение новых инновационных бизнес-моделей, с ориентацией на решение социальных проблем и обеспечения высокого уровня благосостояния общества, на основе европейского опыта.

Ключевые слова: инновационная деятельность, региональная политика, инклюзивность, стратегия развития, европейская интеграция.

\section{ІНКЛЮЗИВНИЙ РОЗВИТОК РЕГІОНІВ УКРАЇНИ В УМОВАХ ЄВРОПЕЙСЬКОЇ ІНТЕГРАЦІї}

Анотація. Мета статті полягає у обгрунтуванні базових засад підвищення рівня інклюзивності економічного розвитку регіонів України на основі розробки власної стратегії розумної спеціалізації. Вивчено існуючі теоретичні підходи до розуміння та формування інклюзивного розвитку. Встановлено, що на регіональному рівні інклюзивність проявляється як засіб досягнення добробуту усіх членів регіональної громади із використанням наявних та створення нових ресурсів для розвитку. Сучасні пріоритети регіональної політики ЄС базуються на принципах солідарності, сприяння економічному прогресу, поліпшенню умов і стандартів життя та корелюють 3 трьома напрямами: стратегія розумного, стійкого та інклюзивного зростання". Інституціалізація європейського вибору України та реалізація положень Угоди про Асоціацію між Україною та СС обумовлює важливість інклюзивної моделі розвитку на регіональному рівні.

Проведено оцінку цільового спрямування та формування регіональної політики ЄС, трансформації ролі регіонів у процесі активізації глобальних процесів та забезпечення сталого зростання. Висвітлено напрями імплементації досвіду країн-членів СС щодо забезпечення економічного розвитку на засадах інклюзивності у стратегічних програмних документах України. Виокремлено чинники, що обумовлюють необхідність інтенсифікації розвитку регіонів на засадах інклюзивності. Наголошено на важливості використання інноваційної діяльності у процесі забезпечення інклюзивного економічного зростання та соціального добробуту та показано взаємозв'язок між інноваційною діяльністю, інклюзивністю та добробутом.

Проведено оцінку диференціації соціально-економічного розвитку регіонів України та встановлено недостатню дієвість існуючої моделі інклюзивного розвитку. Запропоновано етапність та напрями розробки регіональної стратегії розумної спеціалізації для вітчизняних регіонів як пошук ніші для регіону, що передбачає використання результатів інноваційної діяльності, побудови нових інноваційних бізнес-моделей із орієнтацією на розв'язання соціальних проблем (довкілля, зайнятість, подолання соціальної нерівності) та забезпечення високого рівня добробуту громади на основі європейського досвіду реалізації ініціативи “Smart Platform Specialisation”.

Ключові слова: інноваційна діяльність, регіональна політика, інклюзивність, стратегія розвитку, європейська інтеграція. 